Vol. 2 | No. 4 | 2021 | Hal. 330-336

\title{
PEMANFAATAN PUPUK ORGANIK UNTUK MENINGKATKAN KESEJAHTERAAN MASYARAKAT DI MASA PANDEMI COVID-19 MELALUI PERTANIAN ORGANIK
}

\author{
Sunawan*, Mohammad Aly Yahya Avicena, Zulfa Nurimelda, Asti Widya Asmarani, \\ Novita Indriani, Lutfi Najmutsaqib, Marlina Wahyuningtias, Reza Lailatul Fitra, \\ Ahmad Abid Abdillah, Nugraha Putra Pratama, Surya Yasmina Sofa \\ Fakultas Pertanian, Universitas Islam Malang \\ *korespondensi email: sunawan@unisma.ac.id
}

\begin{abstract}
ABSTRAK
Pada masa pandemi COVID-19 ini adalah masa dimana kita harus lebih banyak menggunakan waktu dirumah, untuk menghindari pemaparan virus tersebut. Pemanfaatan waktu ini juga dapat dimanfaatkan petani tanaman pangan untuk menghasilkan tanaman pangan sehat dan ramah lingkungan. Kondisi yang seperti ini juga menarik perhatian mahasiswa untuk menjadikan sebagai topik pengabdian pada masyarakat (PPM) yang dikemas dalam Pengabdian Masyarakat terintegrasi dengan Mahasiswa KSM-T. Bersama Gapoktan Sedono Makmur petani di Desa Wonoanti menggunakan kesempatan ini untuk memanfaatkan pupuk organik untuk menjadikan pertanian organik semakin berkembang dan untuk meningkatkan pertumbuhan dan produksi hasil pertaniannya di masa pandemi.
\end{abstract}

Kata Kunci: masa pandemi; pertanian organik; pupuk organik cair

\section{PENDAHULUAN}

Pandemi COVID-19 ini masih banyak melanda dunia salah satu negara yang terkena dampaknya adalah Indonesia. Virus COVID-19 ini memiliki sifat penularan yang sangat cepat karena melalui udara untuk penyembaran virus tersebut, sehingga segala aktivitas kita diluar rumah sangat dibatasi. Oleh karena itu, banyaknya permasalahan yang dihadapi masyarakat di masa pandemi ini salah satunya adalah dari segi ekonomi.

Desa Wonoanti merupakan salah satu desa yang terletak di Kecamatan Gandusari, Kabupaten Trenggalek ini termasuk desa yang maju dan cenderung homogen. Banyak potensi yang ada di desa ini salah satunya yaitu dibidang kerajinan tangan dan bidang pertanian. Pertanian yang ada di desa wonoanti menjadi salah satu mata pencarian utama masyarakat setempat selain di bidang kerajinan tangan. Petani di desa ini adalah petani tanaman pangan seperti petani jagung, dan petani padi.

Petani yang ada di Desa Wonoanti ini menggunakan sistem pertanian organik akan tetapi masih banyak juga masyarakatnya yang masih menggunakan pupuk anorganik (pabrik). Kebanyakan masyarakatnya belum sadar akan bahayanya penggunaan pupuk anorganik (pabrik) secara berkepanjangan dalam skala besar yang dapat merusak sifat fisik tanah dan hilangnya unsur hara pada tanah. Mulai dari situ, sebagian masyarakatnya berinisiatif untuk membentuk organisasi pertanian yang bisa di kenal dengan Gabungan Kelompok Tani (GAPOKTAN) sebagai wadah masyarakat untuk mengembangkan berbagai teknologi pertanian yang maju dengan menggunakan bahan organik yang ada di lingkungan sekitar. 
Gapoktan yang ada di desa ini sebenarnya sudah berdiri sejak lama, akan tetapi pada beberapa tahun belakangan ini Gapoktan mengalami perubahan yang dulunya masih menggunakan pupuk anorganik (pabrik) sekarang beralih menggunakan pupuk organik. Penggunaan pupuk organik dengan tujuan untuk pengembangan pertanian organik yang sehat dan maju ini mulai digalakkan pada bulan November 2019 oleh Bupati Trenggalek. Masyarakat Desa Wonoanti melalui Gapoktan Sedono Makmur ini melakukan pelatihan pembuatan pupuk organik secara mandiri dengan di fasilitasi oleh pemerintah kabupaten melalui koordinator pertanian organik yang ada di Kabupaten Trenggalek.

Pelatihan yang dilakukan ini bertujuan untuk meningkatkan pertanian organik untuk bisa berkembang dengan baik. Pupuk organik yang di buat di Desa Wonoanti ini juga dilakukan uji coba pengaplikasiannya pada tanaman pangan seperti padi, jagung, dan kedelai. Dari pengaplikasian tersebut ditinjau kembali tanaman yang diberi pupuk organik dan pupuk anorganik (pabrik) apakah bisa sama-sama berkembang dengan baik atau yang menggunakan pupuk organik lebih baik daripada menggunakan pupuk anorganik (pabrik) sehingga petani dapat mengetahui hasil akhir dari pengaplikasian kedua pupuk tersebut pada tanaman pangan.

Pupuk organik adalah pupuk yang berasal dari dekomposisi bahan-bahan organik yang di uraikan (dirombak) oleh mikroba, yang hasilnya dapat menyediakan unsur hara yang dibutuhkan oleh tanaman dan tanah untuk perkembangan dan pertumbuhan tanaman. Pupuk organik sangat penting dikarenakan dapat digunakan sebagai penyangga sifat fisik, kimia dan biologi tanah, sehingga dapat membantu meningkatkan efisiensi pupuk dan produktivitas lahan pertanian. Upaya peningkatan produksi dapat dilakukan dengan penambahan unsur hara makro dan mikro yang bersifat esensial yang dibutuhkan tanaman selama pertumbuhan dan perkembangan (Noerhayati \& Lesmanah, 2018).

Penggunakan pupuk organik pada sistem pertanian organik ini sangat dianjurkan, karena dapat mengurangi penggunakan pupuk anorganik yang secara berlebihan. Penggunakan pupuk anorganik (pabrik) dalam waktu lama dan secara terus menerus dapat mengakibatkat sifat fisik tanak memburuk tanah menjadi pada, terjadi penimbunan fosfat, dan lain-lain. Sehingga, hal ini disebabkan karena kadar bahan organik tanah telah merosot, sehingga perlu memanfaatkan pupuk organik yang dapat menjaga kesuburan tanah dalam jangka panjang karena tidak merusak sifat fisik, kimia, dan biologi tanah (Sholihah \& Nurhidayati, 2018). Sejumlah penelitian telah menunjukkan bahwa pemakaian pupuk organik dapat memberi pertumbuhan dan hasil tanaman yang baik. Penggunaan pupuk organik ini juga telah diteliti pada tanaman selain padi, seperti jagung manis (Supartha et al., 2012), kedelai, cabai, dan tanaman bawang merah (Raksun \& Japa, 2018).

Pupuk yang digunakan di Desa Wonoanti ini adalah pupuk cair dan pupuk padat, akan tetapi petani di desa ini lebih banyak menggunakan pupuk cair ketimbang pupuk padat. Karena pupuk organik cair dapat memberikan unsur hara yang sesuai dengan kebutuhan tanaman, karena bentuknya yang cair, jika terjadi kelebihan kapasitas pupuk pada tanah dengan sendirinya tanaman akan mudah mengatur penyerapan komposisi pupuk yang dibutuhkan. Pemberian pupuk organik cair juga harus memperhatikan konsentrasi atau dosis yang diaplikasikan terhadap tanaman. Penggunaan pupuk organik cair memiliki beberapa kelebihan antara lain yaitu: pengaplikasiannya lebih mudah, unsur hara yang terdapat di dalam pupuk organik cair dapat dengan mudah diserap oleh tanaman dan mengandung mikroorganisme yang jarang dikandung oleh pupuk padat. Menurut (Nur et al., 2018) kelebihan pupuk organik cair adalah dapat secara cepat mengatasi defisiensi unsur hara, tidak masalah dalam pencucian unsur haranya dan mampu menyediankan unsur hara secara cepat. Kegiatan yang dilakukan petani di Desa Wonoanti ini bertujuan untuk meningkatkan pertumbuhan dan produksi hasil pertaniannya di masa pandemi dan 
menjadikan pertanian yang ada di Desa Wonoanti ini menjadi pertanian tanaman pangan yang sehat.

\section{METODE}

Kegiatan pengabdian masyarakat dilaksanakan pada bulan Agustus sampai dengan bulan September tahun 2021. Bertempat di Dusun Wonoanti, Desa Wonoanti, Kecamatan Gandusari, Kabupaten Trenggalek.

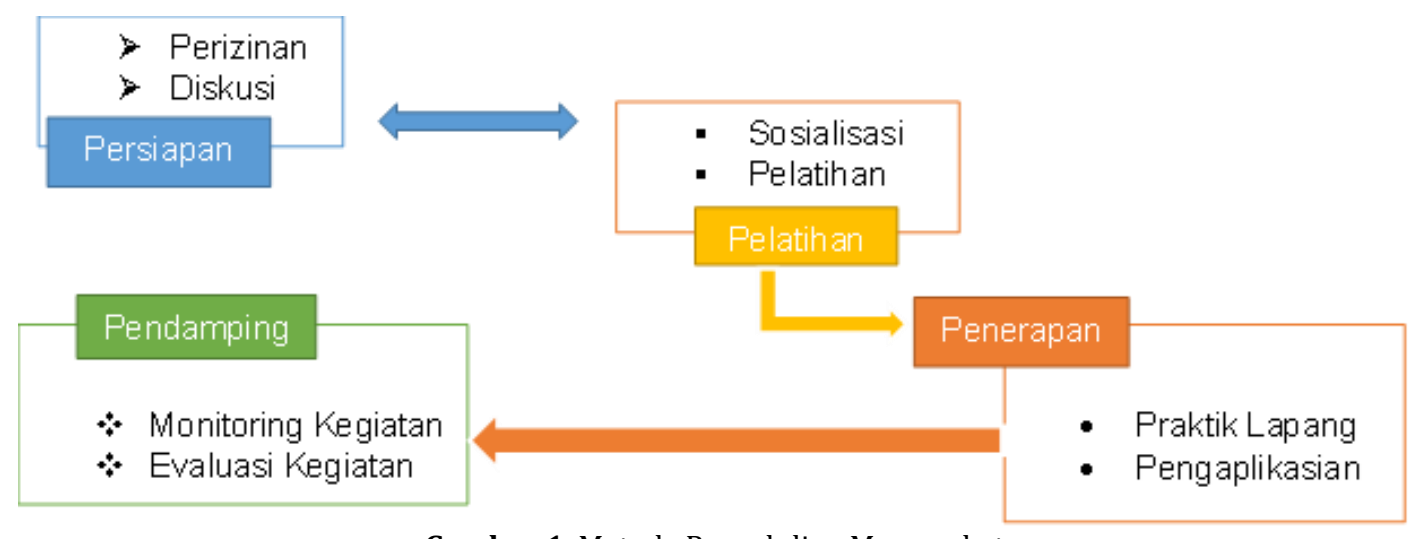

Gambar 1. Metode Pengabdian Masyarakat

Metode kegiatan pengabdian masyarakat yang telat dilaksanakan meliputi persiapan, pelatihan, penerapan dan pendampingan. Masing-masing dari kegiatan ini dilasanakan secara bertahap dan dengan menerapkan tujuan utamanya yaitu menjadikan pertanian organik lebih maju dan berkembang sehingga dapat mengurangi penggunaan pupuk anorganik secara berlebihan. Secara visual dari metode kegiatan ini dapat dilihat sebagai berikut:

Pelaksanaan dari kegiatan pengabdian masyarakat ini dilaksanakan secara bertahap langsung kepada petani. Adapaun pelaksanaan metode persiapan kegiatan ini adalah perizinan dan diskusi. Perizinan dilakukan melalui Kepala Desa dan Sekretaris desa, kemudian Kepala Desa menghubungi Kepala Dusun dan Kepala Dusun menghubungi RT/RW setempat. Diskusi yang dilakukan bersama perangkat desa dan Ketua Gapoktan Desa Wonoanti untuk mengetahui bagaimana cara pembuatan pupuk organik secara mandiri dan bagaimana cara pengaplikasinya kepada tanaman. Adapun tahapan yang dilakukan dalam pelatihan adalah tahap petama yaitu sosialisasi tentang pelatihan pembuatan pupuk organik. Sosialisasi ini bertujuan untuk memberikan gambaran apa saja yang akan dilakukan dalam pembuatan pupuk organik secara mandiri. Yang kedua pelatihan yang dimaksud adalah untuk melatih petani yang ada untuk bisa membuat pupuk organik sendiri-sendiri di rumah. Tahap berikutnya adalah penerapan.

Tahap selajutnya adalah metode pelaksanaan yaitu petani secara langsung praktik atau terjun langsung ke lapang supaya bisa mengetahui cara pembuatan pupuk organik (bahan dan alat apa saja yang digunakan) dan cara mengaplikasikan pupuk organik tersebut pada tanaman. Selain itu petani juga akan di dampingi oleh ketua Gapoktan dan koordinator pertanian organik Kabupaten Trenggalek untuk monitoring dan evaluasi kegiatan yang dilakukan petani menggunakan pupuk organik secara benar. Kegiatan ini dapat dilaksanakan selama kurang lebih 3 bulan. Tujuannya adalah untuk melihat keberhasilan dari kegiatan yang dijalankan. Apabila terdapat kendala selama kegiatan yang dijalankan maka dapat diperbaiki dalam tahap monitoring dan evaluasi. 


\section{HASIL DAN PEMBAHASAN}

\section{Pelatihan Pembuatan Pupuk Organik}

Pelatihan pembuatan pupuk organik dilaksanakan selama 1-2 hari dalam seminggu di Gapoktan Sedono Makmur di Desa Wonoanti dengan sasaran peserta pelatihan yang di bimbing oleh ketua Gapoktan Sedono Makmur dan pihak koordinator pertanian organik Kabupaten Trenggalek. Pelatihan ini bertujuan untuk memberikan gambaran umum tentang pembuatan pupuk organik secara mandiri sehingga petani bisa membuatnya sendiri dirumah masing-masing. Dokumentasi tentang pelatihan pembuatan pupuk organik ini bisa diliat pada gambar 2. Sebelum dilakukan pelatihan, peserta pelatihan diberikan wawasan pengetahuan dan pemahaman tentang pertanian organik dan cara pembuatan pupuk organik ini sehingga peserta pelatihan bisa memahami secara baik bagaimana cara pembuatannya.

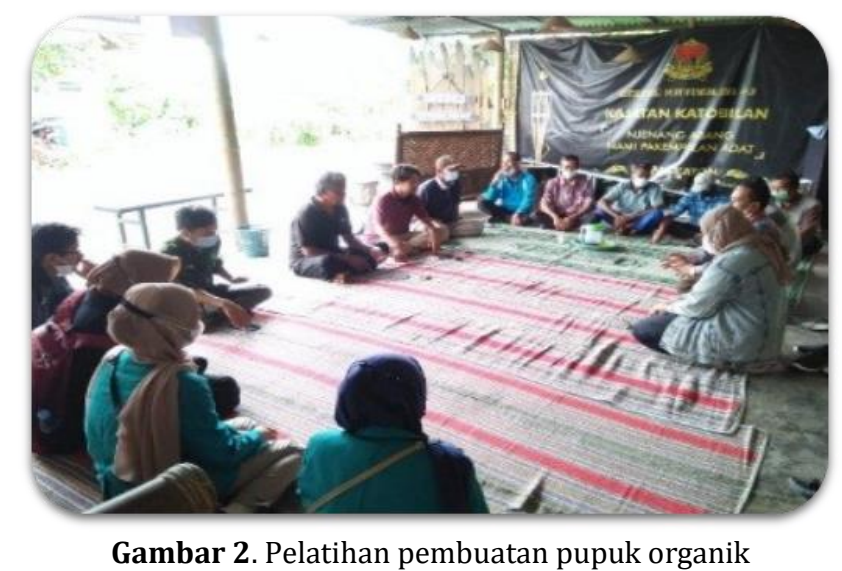

Pembuatan pupuk organik secara mandiri ini bertujuan untuk mengurangi penggunaan pupuk anorganik (pabrik) secara berlebihan karena dapat merusak sifat fisik, kimia, dan biologi tanah. Penggunaan pupuk organik ini juga dapat mengembalikan unsur hara pada tanah yang hilang dan dapat mempercepat laju unsur hara dan pertumbuhan tanaman. Pelatihan ini adalah dasar dari pemahaman peserta pelatihan supaya bisa berangsur-angsur meninggalkan penggunaan pupuk anorganik (pabrik) secara total dengan mengganti menggunakan pupuk organik yang lebih ramah lingkungan, jika hasil pertanian yang diberi pupuk organik lebih menguntungkan hasilnya dibandingkan menggunakan pupuk anorganik (pabrik).

Pupuk organik cair yang di buat di Gapoktan Sedono Makmur Desa Wonoanti berbahan dasar minyak bekas yang telah difermentasi terlebih dahulu kemudian bisa dicampurkan dengan bahan-bahan lain untuk pembuatan pupuk carbon. Bahan yang harus digunakan untuk pembuatan pupuk ini cukuplah sederhana yaitu minyak bekas yang telah difermentasi, air leri (air beras), obat tetes tebu, dan probiotik. Proses Pembuatan Juga Cukup Sederhana Yaitu Air Leri (Air Beras) Bagi Menjadi 2 Bagian, Bagian Pertama Campur Dengan Obat Tetes Tebu Aduk Hingga Tercampur Rata Kemudian Campur Dengan Probiotik Dan Tambah Sisa Air Leri (Air Beras) Kemudian Aduk Hingga Tercampur Rata, Setelah Itu Masukkan Minyak Bekas Kedalam Campuran Air Leri (Air Beras), Probioti Dan Obat Tetes Tebu Aduk Hingga Tercampur Setelah Itu Tutup Timba Yang Digunakan Tadi Secara Rapi Dan Rapat Agar Udara Tidak Bisa Masuk Kedalamnya Dan Diamkan Selama Kurang Lebih 2 Minggu Sampai 1 Bulan. 


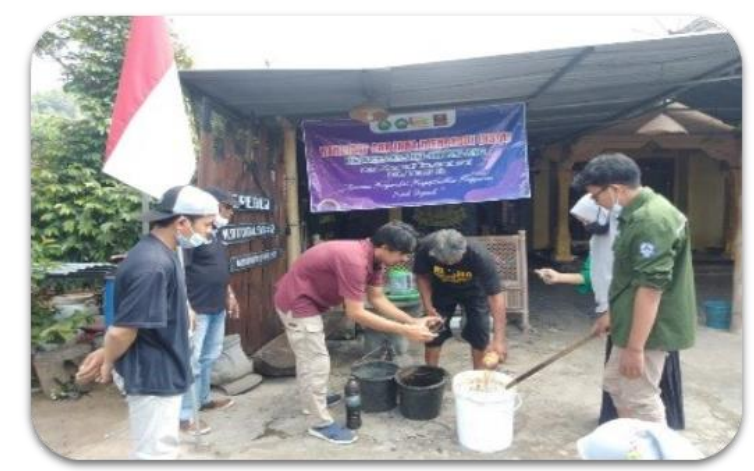

Gambar 3. Pembuatan pupuk organik cair

Selain pupuk organik carbon di Gapoktan Sedono Makmur juga memproduksi atau membuat pupuk organik cair hayati yang berbahan dasar tanaman kentang. Pupuk organik ini dibuat sebagai campuran pupuk carbon untuk penyemprotan ke tanaman pangan. Pembuatan pupuk ini juga cukup sederhana yaitu merebus tanaman kentang yang sudah dibersihkan, dikupas dan di hancurkan terlebih dahulu sampai benar-benar larut dengan api sedang, kemudian tunggu beberapa menit agar dingin kemudian saring dan masukkan air rebusan kentang kedalam galon air kemudian tutup rapat dan diamkan selama \pm 6 jam. Setelah itu rebusan air kentang beri bakteri untuk membantu fermentasi agar air kentang dengan bakteri tadi bisa terurai dan bisa menjadi pupuk organik cair yang ramah lingkungan. Setelah itu pasang selang putih pada galon air dan yang satunya pada botol aqua 1,5 liter yang sudah diberi air kemudian nyalakan alat yang digunakan sebagai alat penggeraknya setelah itu diamkan selama 1 minggu.

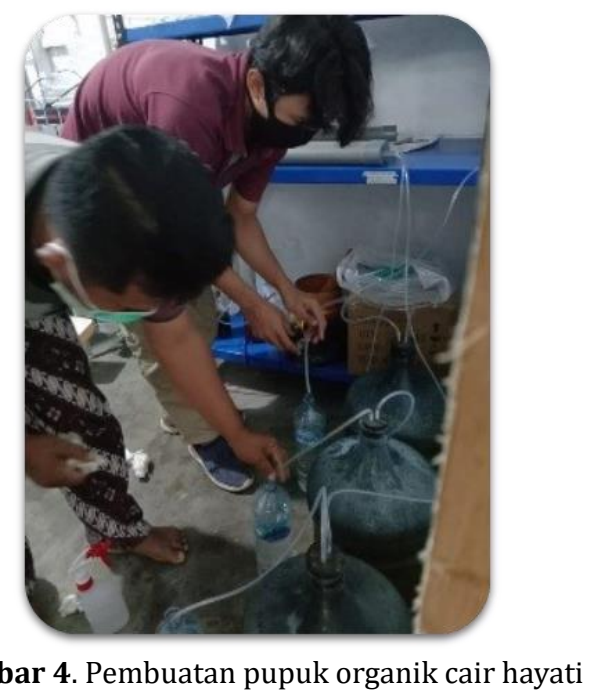

\section{Pengaplikasian Pupuk Organik Pada Lahan}

Pupuk organik yang ada di Gapoktan Sedono Makmur Desa Wonoanti ini, apabila sudah siap untuk diaplikasikan pada tanaman dan lahan pertanian maka ketua Gapoktan Bapak Suparno atau biasa di Panggil dengan Mbah Parno akan menginformasikan kepada petani yang ada di Desa Wonoanti untuk berkumpul di Gapoktan Sedono Makmur. Tujuannya untuk memberikan arahan penggunaan pupuk organik ini dengan dosis yang sudah ditentukan dan bagaimna cara pengaplikasiannya pada tanaman yang baik dan benar. Ukuran untuk pupuk cair ini adalah 2-3 tutup botol aqua atau $1 \mathrm{ml} / \mathrm{liter}$ untuk 1 liter air dan bisa dicampurkan dengan pupuk organik cair yang lain untuk menghasilkan hasil tanaman yang baik. 
Pengaplikasian pupuk organik ini dengan cara menyemprotkan pada daun tanaman seperti tanaman padi, jagung, kedelai. Manfaat dari pemumpukan ini adalah sebagai perekat nitrogen dalam bentuk unsur dan dapat menutrisi daun dan tanah dari proses pelapukan yang ada dan menjadi unsur hara bagi tumbuhan.

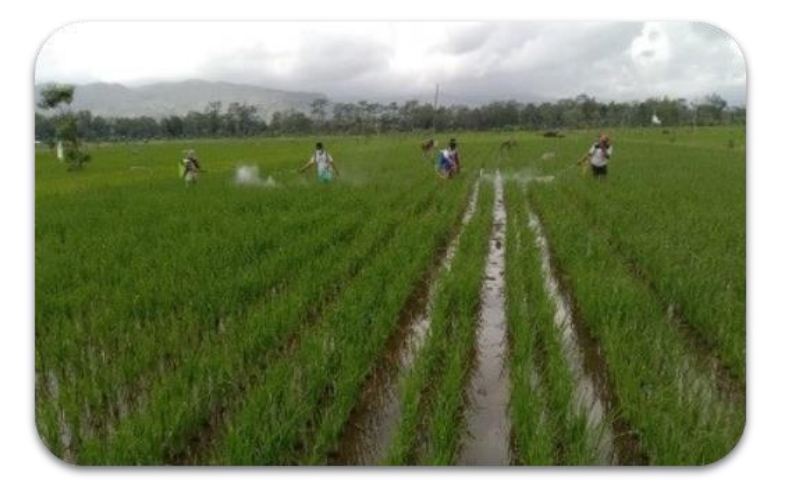

Gambar 5. Penyemprotan pupuk organik cair pada tanaman padi

3. Pengalihan Penggunaan Pupuk Dari Pupuk Anorganik (Pabrik) ke Pupuk Organik

Proses pengalihan yang dimaksud ini adalah membantu petani untuk meninggalkan penggunaan pupuk anorganik (pabrik) secara bertahap ke pupuk organik, dikarenakan penggunaan pupuk organik lebih banyak manfaatnya untuk tanaman dan tanah. Pupuk kimia yang digunakan secara terus menerus dapat menyebabkan peranan pupuk kimia menjadi tidak efektif. Ketidak efektifnya peranan pupuk kimia ini disebabkan tanah pertanian menjadi jenuh oleh residu sisa-sisa bahan kimia yang ada. Menurut Sutanto (2002) pemakaian pupuk kimia secara terus menerus menyebabkan ekosistem biologi tanah menjadi tidak seimbang, sehingga tujuan pemupukan untuk mencukupi unsur hara di dalam tanah di dapat dicapai. Sehingga potensi genetiss tanaman pun tidak dapat dicapai mendekati maksimal.

Oleh sebab itu penggunaan pupuk organik lebih tepat untuk mengatasi masalah yang ditimbulkan oleh penggunaan pupuk anorganik (pabrik) yang digunakan secara berlebih tersebut. Seperti halnya petani sekarang yang ada di Desa Wonoanti ini secara berangsur - angsur berpindah dari yang dulunya menggunakan pupuk anorganik (pabrik) ke pupuk organik. Karena dalam suatu usahatani tidaklah selamanya akan berhasil atau berjalan dengan lancar atau mengakibatkan kegagalan panen, sehingga petani mengalihkan fungsi lahan sawah untuk kepentingan lain. Selain itu untuk pertumbuhan laju produktivitas tanah sawah intensifikasi saat ini mengalami leveling off, yang dimana peningkatan penambahan unit input tidak dapat diikuti peningkatan produktivitas secara ekonomis (Aldillah, 2016).

Sehingga petani Desa Wonoanti sekarang lebih berhati-hati dalam menentukan pengambilan keputusan dalam penggunaan pupuk untuk usahatani yang mereka jalankan. Maka dari itu dari pihak koordinator pertanian organik Kabupaten Trenggalek menerapkan sosialisasi guna untuk menyadarkan betapa pentingnya pupuk organik pada tanaman. Sehingga petani melakukan pemupukan menggunakan pupuk organik untuk menambah unsur hara yang dibutuhkan tanaman, sebab unsur hara yang ada ditanah tidak selalu mencukupi untuk memacu pertumbuhan tanaman secara optimal (Salikin, 2003).

\section{KESIMPULAN}

Melalui kegiatan pelatihan yang diadakan di Gapoktan Sedono Makmur ini, peserta pelatihan yang sebelumnya belum memahami apa itu pertanian organik dan pupuk organik 
secara menyeluruh dan cara pembuatan pupuk organik. Setelah melakukan kegiatan pelatihan ini diharapkan petani yang ada di Desa Wonoanti ini bisa mengembangkan pupuk organik secara mandiri supaya dikemudian bisa mengaplikasikan pupuk organik olahan sendiri ke tanman yang akan ditanaman dan bisa menjadikan pertanian organik yang ada di Desa Wonanti ini semakin maju dan berkembang sampai keluar Desa bahkan Kota lain.

\section{UCAPAN TERIMA KASIH}

Penulis ingin mengucapakan terima kasih kepada Lembaga Penelitian dan Pengabdian Masyarakat (LPPM) Universitas Islam Malang melalui kegiatan Kandidat Sarjana Mengabdi-Tematik (KSM-T) tahun 2021 telah mengadakan kegiatan pengabdian masyarakat ini sehingga kegiatan ini terlaksana dengan baik. Selain itu juga, penulis mengucapkan terima kasih kepada Gapoktan Sedono Makmur di Desa Wonoanti, Kecamatan Gandusari Kabupaten Trenggalek atas partisipasinya dalam kegiatan pengabdian ini dan penulis mengucapkan kepada Dosen Pembimbing Lapang (DPL) dan Anggota kelompok 94 yang telah membantu penulis dalam menyelesaikan tulisannya ini.

\section{DAFTAR RUJUKAN}

Aldillah, R. (2016). Agricultural Mechanization and Its Implications for Food Production Acceleration in Indonesia. Forum Penelitian Agro Ekonomi, 34(2), 163-177. https://doi.org/10.21082/fae.v34n2.2016.163-171

Noerhayati, E., \& Lesmanah, U. (2018). IbM Pemanfaatan Limbah Ternak Kelompok Tani Kedung Sumber Kab. Bojonegoro. Jurnal Inovasi Hasil Pengabdian Masyarakat (JIPEMAS), 1(2), 149-151. https://doi.org/10.33474/jipemas.v1i2.1520

Nur, T., Noor, A. R., \& Elma, M. (2018). Pembuatan Pupuk Organik Cair Menggunakan Biokatalisator Biosca dan EM4. Konversi, 5(2), 5.

Raksun, A., \& Japa, L. (2018). Aplikasi Pupuk Organik untuk Meningkatkan Pertumbuhan Kacang Tanah (Arachis hypogaea L). J.Pijar MIPA, 13(2), 137-139. https://doi.org/10.1201/9781351072533

Salikin, K. A. (2003). Sistem Pertanian Berkelanjutan. Kanisius.

Sholihah, A., \& Nurhidayati. (2018). IbM Kelompok Tani Hortikultura Dalam Rangka Perbaikan Manajemen Produksi Kompos. Jurnal Inovasi Hasil Pengabdian Masyarakat (JIPEMAS), 1(2), 94-104. https://doi.org/10.33474/jipemas.v1i2.1513

Supartha, I. N. Y., Wijana, G., \& Adnyana, G. M. (2012). Aplikasi Jenis Pupuk Organik pada Tanaman Padi Sistem Pertanian Organik. E-Jurnal Agroekoteknologi Tropika, 1(2), 98-106. https://ojs.unud.ac.id/index.php/JAT/article/view/2178

Sutanto, R. (2002). Penerapan pertanian organik : Pemasyarakatan dan pengembangannya (1 (ed.)). Kanisius. 